\title{
Effect of Prymnesium parvum Toxin, Cetyltrimethylammonium Bromide and Sodium Dodecyl Sulphate on Bacteria
}

\author{
By S. ULITZUR AND M. SHILO \\ Department of Microbiological Chemistry, \\ Hebrew University-Hadassah Medical School, Jerusalem, Israel
}

(Accepted for publication 20 May 1970)

SUMMARY

At low concentrations $\left(0.03\right.$ to $3 \mu \mathrm{g} . / 10^{9}$ cells $)$, purified prymnesium toxin lysed penicillin and lysozyme-EDTA spheroplasts of Escherichia coli and Pseudomonas fluorescens and protoplasts of Micrococcus lysodeikticus and Bacillus subtilis. Intact $E$. coli and P. fluorescens were unaffected by the toxin $(3.3 \mu \mathrm{g} . / \mathrm{ml}$.), but $E$. coli B was lysed by prymnesium toxin in the presence of EDTA. The activities of selected detergents against spheroplasts and EDTA-treated $E$. coli B were compared with the action of prymnesium toxin.

\section{INTRODUCTION}

The toxins produced by the phytoflagellate Prymnesium parvum have a wide range of biological activity, including lysis of various mammalian erythrocytes (Yariv \& Hestrin, I96I ; Bergmann \& Kidron, I966) and nucleated cells such as Ehrlich ascites cells (Dafni \& Shilo, I966; Dafni, I969), HeLa cells, and normal liver and amnion cells (Shilo \& Rosenberger, 1960). Common to all these toxin effects is damage to the cytoplasmic membrane and one result of this is leakage of intracellular constituents into the medium. Prymnesium extracts, including the highly purified preparations, lead to changes in the potassium and sodium content of Ehrlich ascites cells with very rapid leakage (within $20 \mathrm{sec}$.) of most of the intracellular potassium (Dafni, I969). Furthermore, the primary effect of the prymnesium ichthyotoxin on immersed fish seems to be the loss of selective permeability of the gill epithelial cells towards various substances, including macromolecules such as trypan blue or radio-iodinated albumin (Ulitzur \& Shilo, 1966).

This study describes the effects of prymnesium toxin on bacteria (intact organisms, protoplasts, spheroplasts, and also species of Mycoplasma). The similarity of chemical and physical properties of various detergents (cetyltrimethylammonium bromide and sodium dodecyl sulphate) to those of prymnesium toxin (Ulitzur \& Shilo, I966, 1970) made their testing in this experimental system of interest.

\section{METHODS}

Prymnesium parvum toxin. The intracellular toxic principle ('toxin B') was extracted and purified as described previously (Ulitzur, 1969; Ulitzur \& Shilo, 1970). The purified 'toxin B' preparation had a specific activity of 3000 haemolytic units (h.u.)/ $\mu \mathrm{g}$., and was dissolved in methanol. In the experimental systems, the final methanol 
concentration was never greater than $\mathrm{O} \cdot \mathrm{I} \%$; this concentration did not affect the bacteria tested. For alkaline treatment of the toxin, $0.5 \mathrm{~N}-\mathrm{NaOH}$ (in methanol) was mixed with toxin and incubated for $30 \mathrm{~min}$. at $20^{\circ}$ and then neutralized by addition of $\mathrm{I} \mathrm{N}-\mathrm{NaCl}$ (in methanol). For several experiments, 'toxin B' was separated into six components by thin-layer chromatography (Ulitzur \& Shilo, 1970).

Bacterial strains and growth conditions. The bacterial strains used were Escherichia coli $\mathrm{B}, E$. coli $\mathrm{KI} 2, E$. coli $\mathrm{ML} 35$ (a lactose permeaseless mutant with constitutive $\beta$-galactosidase $\left(i^{-} z^{+} y^{-}\right)$), Pseudomonas fluorescens MD9 (an isolate described by Rosenberger \& Shilo, 196I), Bacillus subtilis w I68, and Micrococcus lysodeikticus (all from the collections of the Departments of Bacteriology and Microbiological Chemistry of the Hebrew University-Hadassah Medical School, Jerusalem). Bacteria were grown in nutrient broth (Difco) at $37^{\circ}$ with shaking and harvested at the logarithmic phase of growth by centrifugation at $10,000 \mathrm{~g}$ for $15 \mathrm{~min}$. at $20^{\circ}$. They were washed and resuspended in $0.05 \mathrm{M}$ buffer $\left(\mathrm{pH}_{7} \cdot 6\right)$.

Mycoplasma capri and $M$. laidlawii (obtained from S. Razin, Department of Clinical Bacteriology, Hebrew University-Hadassah Medical School, Jerusalem) were grown as described by Razin (1963).

Preparation of spheroplasts and protoplasts. Lysozyme-EDTA spheroplasts of Escherichia coli and Pseudomonas fluorescens were prepared as described by Repaske (1958). Protoplasts of the Gram-positive organisms were obtained by incubation of $2 \times 10^{10}$ bacteria $/ \mathrm{ml}$. in buffer (0.0I M-tris, $0.05 \mathrm{M}-\mathrm{NaCl}$ and I M-sucrose at $\mathrm{pH} 8$ ) with the addition of $100 \mu \mathrm{g}$. lysozyme (Fluka) and $20 \mu \mathrm{g}$. DNase (Calbiochem) per ml. After incubation of this mixture for $30 \mathrm{~min}$. at $30^{\circ}$, phase contrast microscopy showed that at least $90 \%$ of the organisms were converted into protoplasts. The protoplasts were centrifuged at $5000 \mathrm{~g}$ for $20 \mathrm{~min}$. at $4^{\circ}$ and resuspended in the buffer. Penicillin spheroplasts of $E$. coli and $P$. fluorescens were prepared by growth in nutrient broth containing $0.6 \mathrm{M}$-sucrose. When the bacterial population reached $5 \times 10^{7}$ organisms $/ \mathrm{ml}$., I000 u. penicillin $\mathrm{G}_{i}^{/ \mathrm{ml}}$. (potassium salt; Rafa, Jerusalem) were added. Microscopic examination showed that, after 2 to $3 \mathrm{~h}$. incubation, more than $90 \%$ of the organisms were converted into spheroplasts. Spheroplasts and protoplasts were stored at $4^{\circ}$.

Determination of lytic effect of prymnesium toxin on intact and osmotically sensitive bacteria. Assay mixtures containing $10^{9}$ spheroplasts, protoplasts, or mycoplasma organisms $/ \mathrm{ml}$. in $6 \mathrm{ml}$. of various isotonic buffers and different concentrations of prymnesium toxin or detergents were incubated at $35^{\circ}$ for $\mathrm{I} h$. or at $8^{\circ}$ for $\mathrm{I} 7 \mathrm{~h}$. The degree of lysis was determined by following the decrease in turbidity in a KlettSummerson photometer (filter 42). Untreated cell suspensions were used as controls. Complete ( $100 \%$ ) lysis was obtained by adding $9 \mathrm{ml}$. water to $\mathrm{I} \mathrm{ml}$. of bacterial suspension ( $\mathrm{IO}^{10}$ cells) and incubating the diluted suspension for $30 \mathrm{~min}$. at $20^{\circ}$. This system was also used for testing the lytic effects of prymnesium toxin, sodium dodecyl sulphate (SDS, Fluka) and cetyltrimethylammonium bromide (CTAB, Fluka) on intact Escherichia coli $\mathrm{B}$ and E. coli $\mathrm{K} \mathrm{I} 2$ in the presence or absence of $2 \times 10^{-4} \mathrm{M}$ sodium ethylenediaminetetra-acetate (EDTA).

Viable count of bacteria. The bacterial suspension was incubated for $3 \mathrm{~h}$. at room temperature in $0.05 \mathrm{M}$-tris buffer $\left(\mathrm{pH}_{7} .6\right)$ with prymnesium toxin. The control contained the same mixture with suitable concentrations of methanol instead of toxin. After incubation the bacteria were diluted and plated on nutrient agar (Difco). Colonies were counted after incubation for $24 \mathrm{~h}$. at $37^{\circ}$. 
Assay of $\beta$-galactosidase activity. Hydrolysis of $o$-nitrophenyl- $\beta$-D-galactopyranoside (ONPG) by Escherichia coli ML 35 was carried out as described by Wallenfels, Lehman \& Malhotra (1962).

\section{RESULTS}

The effect of prymnesium toxin on bacterial spheroplasts and protoplasts and on Mycoplasma. Prymnesium toxin lysed penicillin and lysozyme-EDTA spheroplasts of Pseudomonas fluorescens and Escherichia coli as shown in Fig. I. The minimal dose which lysed $50 \%$ of the organisms was found to be independent of the method used for preparing the spheroplasts. The toxin also lysed protoplasts of Bacillus subtilis and

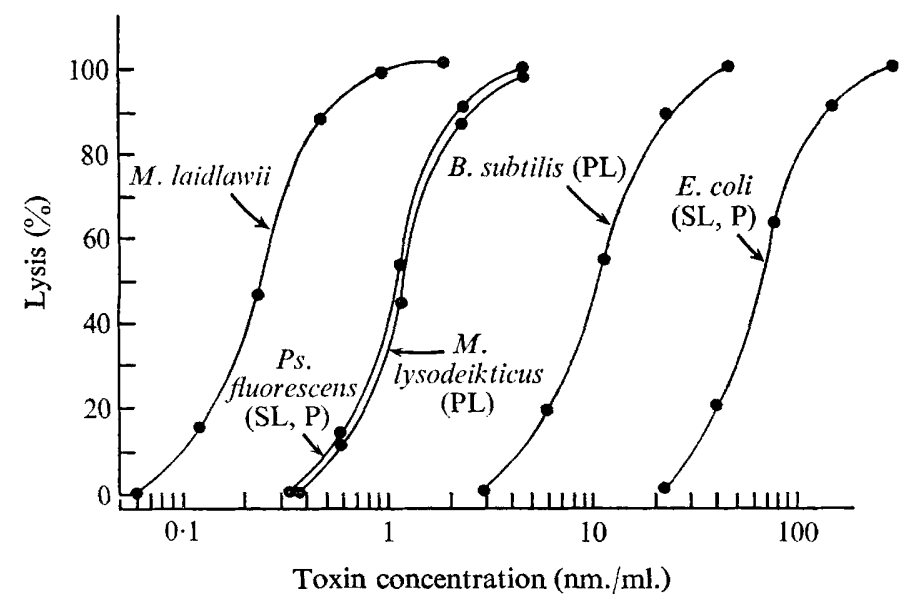

Fig. I

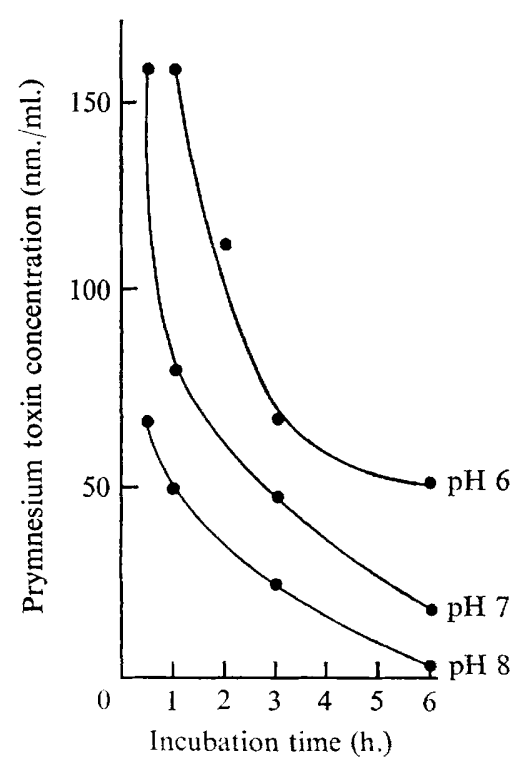

Fig. 2

Fig. I. The lytic activity of prymnesium toxin on spheroplasts, protoplasts and mycoplasma organisms. Escherichia coli and Pseudomonas fluorescens spheroplasts were suspended in $0.3 \mathrm{M}$-sucrose in $0.06 \mathrm{M}$-tris buffer ( $\mathrm{pH} 8$ ). Bacillus subtilis and Micrococcus lysodeikticus were suspended in $1 \mathrm{M}$-sucrose and $0.005 \mathrm{M}-\mathrm{NaCl}$ in $0.01 \mathrm{M}$-tris buffer $(\mathrm{pH} 8)$, and the mycoplasma organisms were suspended in $0.04 \mathrm{M}$-sucrose and $0.25 \mathrm{M}-\mathrm{NaCl}$ in $0.02 \mathrm{M}$-tris buffer (pH 8). The degree of lysis was determined after $\mathrm{I} \mathrm{h}$. at $35^{\circ}$ as described in Methods. $\mathrm{PL}=$ protoplasts prepared with lysozyme; $\mathrm{SL}=$ spheroplasts prepared by the lysozymeEDTA method; $\mathbf{P}=$ spheroplasts prepared with penicillin.

Fig. 2. The effect of $\mathrm{pH}$ on the lytic activity of prymnesium toxin. The incubation time which gave lysis of $50 \%$ of Pseudomonas fluorescens lysozyme-EDTA spheroplasts was determined in the presence of different toxin concentrations in a solution of $0.3 \mathrm{M}$-sucrose at different $\mathrm{pH}$ values (in $0.02 \mathrm{M}$-sodium phosphate buffer) at $35^{\circ}$.

Micrococcus lysodeikticus and Mycoplasma laidlawii organisms (Fig. I). The sensitivity of mycoplasma organisms to the toxin was more than 500 times that of the $E$. coli spheroplasts. Micrococcus capri was even more sensitive: $0.05 \mathrm{~nm}$. toxin $/ \mathrm{ml}$. lysed $50 \%$ of the $M$. capri population under the same conditions. The sensitivity of Escherichia coli spheroplasts to prymnesium toxin was more than Io times greater than their sensitivity to CTAB and 500 times greater than their sensitivity to SDS on a weight basis.

Figure 2 shows that the lytic activity of the toxin on Pseudomonas fluorescens sphero24 
plasts increased progressively when the $\mathrm{pH}$ of the system increased from 6 to 8 . Figure 3 shows that toxin pretreated with $\mathrm{NaOH}$ had practically no lytic effect on $P$. fuorescens spheroplasts when incubated at $35^{\circ}$. However, such pretreated toxin retained some of its original lytic activity when tested at $8^{\circ}$. Tabor, Tabor \& Rosenthal (I96I) showed that divalent cations $\left(\mathrm{Mg}^{2+}\right.$ and $\mathrm{Ca}^{2+}$ ) and polycationic substances (spermine) stabilized osmotically sensitive spheres in hypotonic media. We found that spermine or $3^{\prime}, 3$-diaminodipropylamine markedly protected Mycoplasma laidlawii against the lytic activity of the prymnesium toxin. It was found that, while $0.5 \mu \mathrm{g}$. toxin $/ \mathrm{ml}$. gave $50 \%$ lysis in the absence of these bases, $25 \mu \mathrm{g} . / \mathrm{ml}$. were required in the presence of spermine $(0.00 \mathrm{I} \mathrm{M})$ and $30 \mu \mathrm{g} . / \mathrm{ml}$. in the presence of $3^{\prime}, 3$-diaminodipropylamine (0.00I5 M).

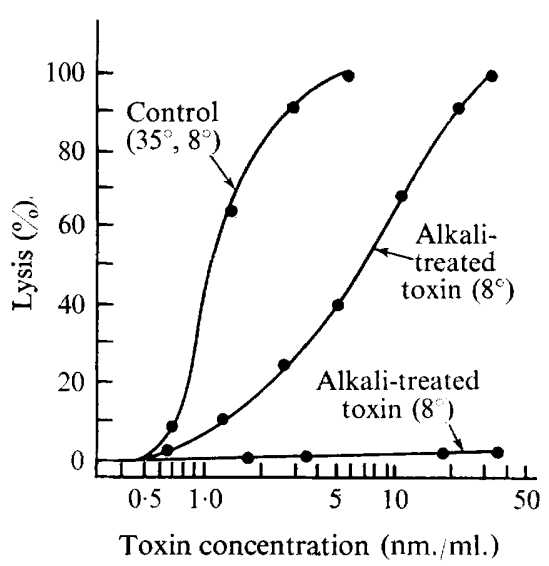

Fig. 3

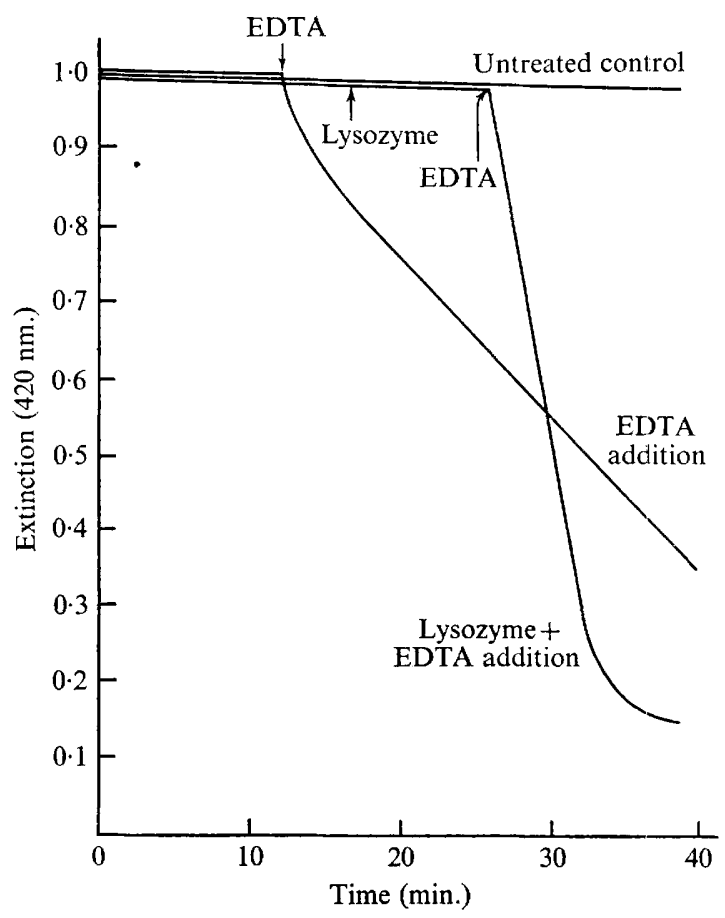

Fig. 4

Fig. 3. The lysis of Pseudomonas fluorescens spheroplasts by $\mathrm{NaOH}$-treated prymnesium toxin. The lytic activity was determined before (control) and after the toxin had been treated with $\mathrm{NaOH}$ (as described in Methods); the extent of lysis was determined at $35^{\circ}$ after $60 \mathrm{~min}$. and at $8^{\circ}$ after $17 \mathrm{~h}$., a time after which no further lysis occurred.

Fig. 4. The effect of prymnesium toxin on EDTA-treated Escherichia coli B. At a final concentration of $10^{9}$ organisms $/ \mathrm{ml}$. E. coli B were suspended in $0.3 \mathrm{M}$-sucrose in $0.05 \mathrm{M}$-tris buffer (pH 8) containing $0.66 \mu \mathrm{g}$. prymnesium toxin $/ \mathrm{ml}$. EDTA $\left(2 \times 10^{-4} \mathrm{M}\right)$ and lysozyme $(10 \mu \mathrm{g} . / \mathrm{ml}$. were added to the mixture as indicated by arrows. The rate of lysis at $22^{\circ}$ was determined in a Perkin-Elmer spectrophotometer (Model UV 137) at $420 \mathrm{~nm}$. against a cuvette containing only tris-sucrose buffer.

The lytic activity of four of the six haemolytic components separated by thin-layer chromatography (t.1.c.) of 'toxin B' (Ulitzur \& Shilo, 1970) was tested on Pseudomonas fluorescens spheroplasts. All four components showed lytic activity, and for each the ratio of lytic to haemolytic activity was similar. 
The effect of prymnesium toxin on intact cells. Untreated logarithmic-phase Escherichia coli ML 35 and Pseudomonas fluorescens bacteria were resistant to prymnesium toxin. No decreases in viable counts occurred when these bacteria were treated with $3.3 \mu \mathrm{g}$. toxin $/ \mathrm{ml}$. at $35^{\circ}$ for $3 \mathrm{~h}$. This concentration of toxin is 100 times that sufficient to lyse spheroplasts of $E$. coli. Incubation of $E$. coli ML 35, a strain cryptic for $\beta$-galactosidase, with $3.3 \mu \mathrm{g}$. toxin $/ \mathrm{ml}$. under similar conditions did not result in any detectable cell membrane damage as determined by the ability of such cells to hydrolyse ONPG.
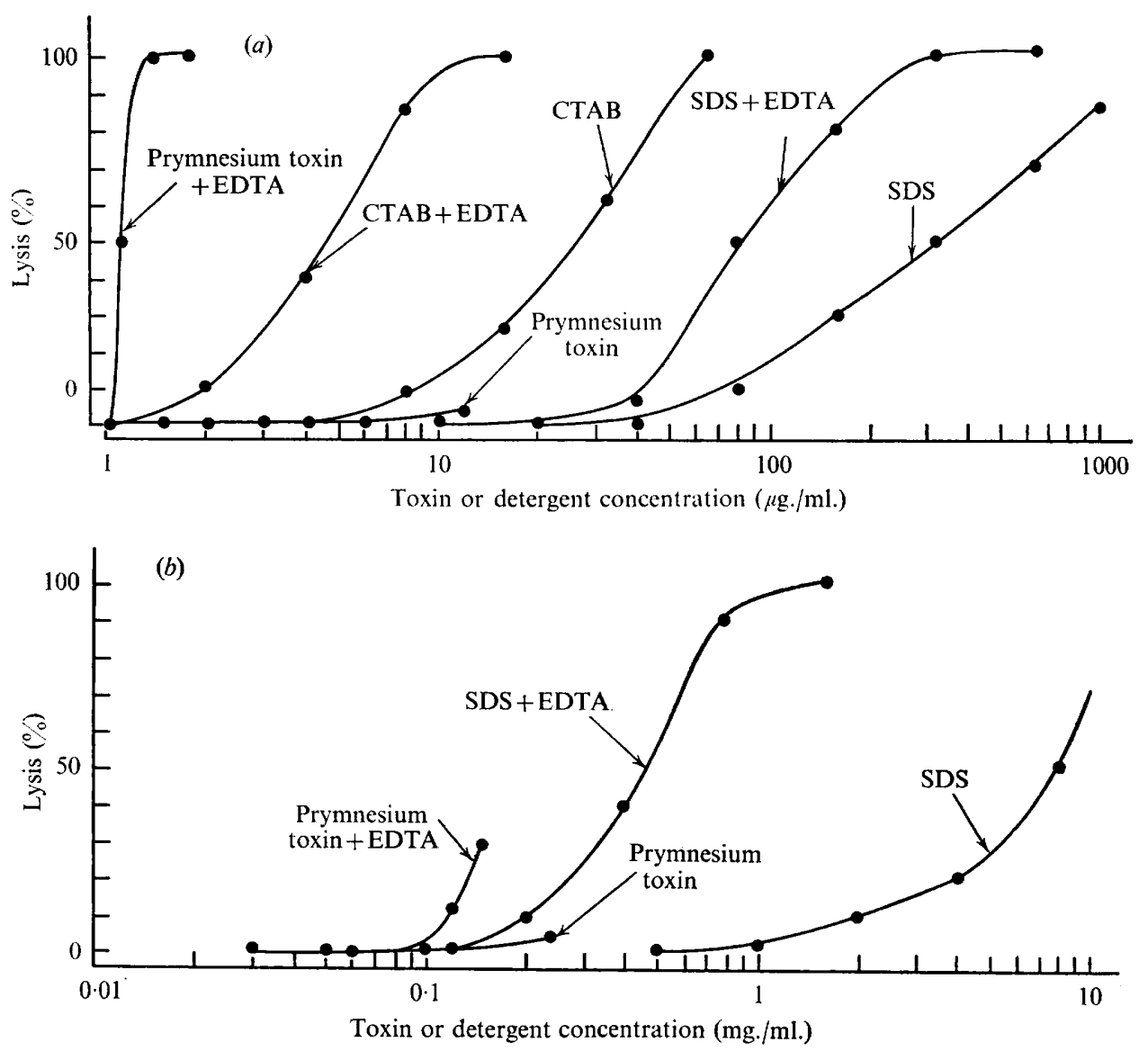

Fig. 5. The lytic effect of prymnesium toxin, SDS, and CTAB on EDTA-treated Escherichia coli $\mathrm{B}(a)$ and $E$. coli $\mathrm{K} \mathbf{2}(b)$. Both strains of $E$. coli were studied in systems without and with EDTA $\left(2 \times 10^{-4} \mathrm{M}\right)$ and lysis measured after $60 \mathrm{~min}$. at $35^{\circ}$. E. coli $\mathrm{B}$ was suspended in sucrosetris buffer as described in Fig. 4, and E. coli $\mathrm{K} I 2$ was suspended in 0.05 M-tris buffer (pH 8).

It is likely that intact bacteria are resistant to prymnesium toxin because cell-wall components block access of the toxin to the bacterial membrane. EDTA treatment of Escherichia coli has been shown to destroy cell-wall barriers towards certain antibiotics, such as actinomycin D (Leive, 1965a), polymyxin B and novobiocin, as well as towards detergents, such as cetylpyridinium bromide and sodium tetradecyl sulphate, and towards complement (Muschel \& Gustafson, 1968). EDTA-treated cells were therefore tested for their sensitivity to prymnesium toxin. When suspended in 
$0.05 \mathrm{M}$-tris buffer ( $\mathrm{pH} 5), E$. coli $\mathrm{B}$ organisms, but not E. coli $\mathrm{K} 12$ were lysed in the presence of $2 \times \mathrm{IO}^{-4} \mathrm{M}$-EDTA. The sensitivity of EDTA-treated $E$. coli B organisms to prymnesium toxin was therefore tested in the presence of stabilizing concentrations of sucrose $(0.3 \mathrm{M})$. Figure 4 shows that prymnesium toxin alone had no effect on intact $E$. coli B suspended in the sucrose-tris buffer solution. When EDTA $\left(2 \times 10^{-4} \mathrm{M}\right)$ was added to these toxin-treated bacteria, the turbidity decreased. Addition of lysozyme to toxin-treated $E$. coli B had no effect, but subsequent addition of EDTA, which converted the cells into spheroplasts, caused rapid lysis.

The two detergents (SDS and CTAB) tested for their lytic effect on Escherichia coli B showed a four- to fivefold increase of activity in the presence of EDTA (Fig. 5a), similar to the action of prymnesium toxin. Escherichia coli $\mathrm{K} \mathrm{I} 2$, on the other hand, was found to be more resistant to the lytic activity of prymnesium toxin and SDS even in the presence of EDTA (Fig. 5b).

\section{DISCUSSION}

The highly purified prymnesium toxin preparation has been shown to be one of the most active lysins described, having a specific haemolytic activity more than 3000 times that of digitonin or lysolethicin (Ulitzur \& Shilo, I970). It has been suggested that the strong affinity of the toxin towards biological membranes results from its chemical structure which, as with synthetic detergents and lysophospholipids, consists of lipid (fatty acids) and polar (protein and phosphate) moieties (Ulitzur \& Shilo, I970). Unlike most of the ionic detergents which exert lytic activity on intact bacteria (Baker, Harrison \& Miller, I94I; Hotchkiss, I946; Salton, I95I), prymnesium toxin only acts upon bacteria whose cell walls are partially removed and thus resembles some non-ionic detergents and antibacterial agents (such as actinomycin D and complement) which are not capable of affecting certain intact bacteria (Leive, 1965 $a$; Muschel \& Gustafson, 1968).

The resistance of intact bacteria to lysis by prymnesium toxin may be related to the impermeability of the cell wall to the large micelles of the toxin existing in aqueous solutions. On the other hand, it is known that some detergents can affect the metabolism of an organism without affecting its viability (Hotchkiss, 1946). The fact that Escherichia coli ML 35 treated with prymnesium toxin did not become permeable to ONPG indicates that, if indeed it occurs at all, toxin damage to the intact cell membrane was small.

Treatment of bacteria with lysozyme-EDTA or growth in the presence of penicillin, treatments which expose the cell membrane or part of it, rendered the bacteria susceptible to lysis on subsequent exposure to prymnesium toxin. However, this lytic effect on the osmotically sensitive bacteria was very disparate, in contrast to the consistent effect on different sorts of vertebrate erythrocytes; for instance, mycoplasma organisms are highly sensitive to prymnesium toxin, while Escherichia coli spheroplasts are more resistant.

Malamy \& Horecker (1964) have shown that after spheroplast formation by treatment with lysozyme-EDTA, but not by growth in the presence of penicillin, the alkaline phosphatase bound in the periplasm is liberated. In spite of the differences in the nature of spheroplasts formed by lysozyme-EDTA and penicillin treatment, no noticeable differences in sensitivity were observed between the two kinds of spheroplasts towards prymnesium toxin. It appears that the resistance of intact bacteria to 
lysis by prymnesium toxin must depend on the presence of a 'barrier' in the cell wall against the toxin, and not on any particular stability of the cell membrane. This would explain the sensitivity of Escherichia coli $\mathrm{B}$ to toxin (as well as to SDS and CTAB) in the presence of EDTA. As is known, EDTA treatment of $E$. coli liberates a considerable portion of the cell wall lipopolysaccharide (Leive, $1965 b$ ), rendering the cell penetrable to a number of substances which cannot enter the intact organism (or hardly so). Muschel \& Gustafson (1968) have found that EDTA-treated E. coli showed higher sensitivity to ionized detergents, polymyxin $\mathrm{B}$, and complement.

The findings described here indicate that both the haemolysin and the lysin of osmotically sensitive bacteria could be the same toxic principle. This suggestion is based on the similar response to alkaline treatment of both activities, in contrast to the ichthyotoxic activity which is not affected by alkaline treatment (Shilo, 1967). Furthermore, it was found that four out of six of the haemolysins separated by t.l.c. showed lytic activity towards Pseudomonas spheroplasts corresponding to their haemolysin content, while no fixed relationship was observed between their haemolytic and ichthyotoxic activities (Ulitzur \& Shilo, 1970).

Our thanks are due to Professor E. Goldberg for critical reading of the manuscript and to Mrs B. Golek for her aid in preparing the manuscript.

\section{REFERENCES}

Baker, Z., Harrison, R. W. \& Miller, B. F. (1941). Action of synthetic detergents on the metabolism of bacterial cells. Journal of Experimental Medicine 73, 249-27I.

BERgmann, F. \& Kidron, N. (1966). Latent effect of haemolytic agents. Journal of General Microbio$\log y$ 44, 233-240.

DafNi, Z. (1969). Primary effect of Prymnesium parvum cytotoxin. Journal of Protozoology I6, suppl. 138.

DafNi, Z. \& ShILo, M. (I966). The cytotoxic principles of the phytoflagellate Prymnesium parvum. Journal of Cell Biology 28, 46I-47I.

HотсHкiss, R. D. (1946). The nature of the bactericidal action of surface active agents. Annals of the New York Academy of Sciences 46, 479.

LEIVE, L. (1965a). Nonspecific increase in permeability in Escherichia coli produced by EDTA. Proceedings of the National Academy of Sciences of the United States of America 53, 745-750.

LEIVE, L. ( $1965 b)$. Release of lipopolysaccharide by EDTA treatment of E. coli. Biochemical and Biophysical Research Communications 2r, 290-296.

Malamy, M. H. \& HoreckeR, B. L. (1964). Release of alkaline phosphates from cells of Escherichia coli upon lysozyme spheroplast formation. Biochemistry, New York 3, I889-1897.

Muschel, L. H. \& Gustafson, L. G. (i968). Antibiotic, detergent and complement of Salmonella typhi after ethylendiaminetetra-acetic acid treatment. Journal of Bacteriology 95, 2010-2013.

RAZIN, S. (1963). Mycoplasma taxonomy studied by electrophoresis of cell proteins. Journal of Bacteriology 96, 687-694.

REPASKe, R. (1958). Lysis of Gram-negative organisms and the role of versene. Biochimica et Biophysica Acta 30, 225-232.

Rosenberger, R. \& Shilo, M. (I96I). Diauxie in tartrate utilizing strains of Pseudomonas and its control by oxaloacetate. Biochemical and Biophysical Research Communications 4, 4I4-4I9.

SALton, M. R. J. (I95I). The adsorption of cetyltrimethyl ammonium bromide by bacteria, its action in releasing cellular constituents and its bactericidal effects. Journal of General Microbiology 5, 39I-404.

SHILO, M. (1967). Formation and mode of action of algal toxins. Bacteriological Reviews 31, I80-193.

Shilo, M. \& Rosenberger, R. F. (I960). Studies on the toxic principles formed by the chrysomonad Prymnesium parvum Carter. Annals of the New York Academy of Sciences 90, 866-876. 
TABOR, H., TABOR, C. W. \& RoSENTHAL, S. (196I). The biochemistry of the polyamines and spermine. Annual Review of Biochemistry 30, 579-604.

Ulitzur, S. (1969). Purification and separation of the toxins produced by the phytoflagellate Prymnesium parvum. Verhandlungen von der Internationalen Vereinigung fïr theoretische und angewandte Limnologie $\mathbf{1 7}, 771-777$.

Ulitzur, S. \& ShILO, M. (1966). Mode of action of Prymnesium parvum ichthyotoxin. Journal of Protozoology 13, 332-336.

Ulitzur, S. \& ShILo, M. (1970). Purification and separation of the toxic principle of Prymnesium parvum. Biochimica et Biophysica Acta 201, 359-363.

Wallenfels, K., Lehman, J. \& Malhotra, O. P. (1962). In Methods in Enzymology, vol. v, pp. $212-$ 213. New York and London: Academic Press.

YARIV, J. \& HeSTRIN, S. (1961). Toxicity of the extracellular phase of Prymnesium parvum cultures. Journal of General Microbiology 24, 165-175. 